\title{
ZOOLOGY
}

DOI https://doi.org/10.30525/978-9934-26-047-6-8

\section{ПОШУК ПЕРСПЕКТИВИ У ВИРІШЕННІ ДОЦІЛЬНОСТІ ІМУНОЛОГІЧНОЇ КАСТРАЦІЇ СВИНОК}

\author{
Будаква С. О. \\ аспірант спеціальності 204 «Технології виробництвва \\ та переробки продукиії тваринництва» \\ Інститут свинарства і агропромислового виробництва \\ Національної академії аграрних наук України \\ м. Полтава, Украӥна
}

У країнах Свропи багатьох споживачів продукції свинини турбує питання впливу інтенсивних технологій вирощування с.-г. тварин, стан навколишнього середовища, благополуччя тварин. Тому, дане питання $\epsilon$ актуальним у вивченні переваги імунокастрованих свинок від нативних за м'ясною продуктивністю.

3 біологічної точки зору «нативний» - це організм, котрий перебуває у природньому стані. Тобто самки свиней (sus scrofa) відрізняються від імунологічно кастрованих свинок за фізіологічним станом 3 проявом ознак еструса, з настанням фізіологічної зрілості до клімактерії, або до завершального етапу відгодівлі перед відправкою на забій [1, с. 17].

3 точки зору фізіології росту і розвитку біологічного організму самок свиней (sus scrofa) при досягнені віку статевої зрілості 4 місяців, a у помісних самок свиней скороспілих порід прояв поведінкової статевої зрілості настає на 1-1,5 міс. раніше, у яєчниках утворюються статеві клітини, продукуються статеві гормони, котрі визначають статеві ознаки та викликають естральні цикли. У фолікулах утворюється значна кількість гормонів (естрогенів), котрі викликають стан настання охоти. Важливе значення має жовте тіло виділяючи гормон прогестин, котрий відіграє важливу роль в обмінні речовин, підвищує накопичення жиру, впливає на вуглеводний обмін. Головною особливістю самок свиней $є$ циклічність секреції статевих гормонів i прояв статевих ознак. Пояснюється тим, що у самок свиней у період ембріогенеза тестостерон не виділяється, тому циклічність зберігається на весь репродуктивний період. Естроген та прогестерон є основними 34 
статевими гормонами у самок свиней. Дія естрогенів на біологічний організм самок свиней $є$ логічним сенсом у забезпеченні життєдіяльності даного виду. Естрогени відіграють важливу роль в організмі самок свиней, у матці підвищується синтез РНК, естрогени здійснюють великий вплив на гіпофіз 3 вироблення гонадотропних гормонів [2, с. 47].

При досягнені статевої зрілості, організм свинок починає активно продукувати гормони - скатол та андростенон. Скатол є продуктом життєдіяльності бактерій у товстому відділі кишечника, абсорбується через шкіру, відкладається у підшкірно-жировій тканині, що $\epsilon$ причиною виникнення кнурячого запаху.

Питання про благополуччя сільськогосподарських тварин стало вагомим кроком для впровадження імунологічної кастрації свинок, як один із гуманних методів по відношенню до сільськогосподарських тварин на відмінну від оваріоектомії свинок. Так, як традиційний хірургічний метод кастрації «оваріоектомія» супроводжується післяопераційними ускладненнями, з проявом патологічних відхилень, а саме: розрив кишки сечостатевого міхура; випадіння внутрішніх органів - яєчникової, середньої маточної артерії, тощо.

Проект Закону України №3318 «Ветеринарна медицина та благополуччя тварин» передбачає системний контроль 3 метою мінімізації використання антибіотиків та препаратів в тваринництві, розвитку ветеринарної практики, що сприятиме благополуччю сільськогосподарських тварин, здоров'ю людей при споживані безпечної продукції зі свинини.

Імунологічна кастрація $€$ альтернативним методом хірургічній кастрації свинок, дозволяє підтримувати високу якість продуктів забою 3 низьким рівнем прояву кнурячого запаху. Імунологічна кастрація $\epsilon$ доцільним ветеринарним заходом при інтенсивній технології вирощування і реалізації молодняку свиней великими одновіковими групами.

Препарат «Improvac» - це білкова молекула, котра діє через імунну систему свинок, забезпечуючи тимчасовий ефект імунологічної кастрації свинок, виводячи речовини (стероїдні гормони), котрі викликають кнурячий запах. Проведення імунізації препаратом «Improvac» знижує рівень кнурячого запаху, смаку м’яса та сала через пригнічення на гормональному рівні гонадотропін-рилізинг фактору (GnRF), знижується прояв поліциклічності, за рахунок кон'югату, імунізуючого препарату, підсилюється рівень тривалості імунітету під час вирощування та відгодівлі до забою. 
Генетично-селекційна робота у напрямку пригнічення успадкування андростенона та скатола - прояв кнурячого запаху, на сьогоднішній день $є$ значущим питанням. Так, як невідомо, які гени відповідають за кнурячий запах, проведення геномного відбору стане перспективним рішенням у виключенні необхідності проведення ветеринарних заходів імунологічної кастрації та хірургічної кастрації, оскільки з'явиться прямий зв'язок з тим, які алелі та локуси кількісних ознак $\epsilon$ полігенними [3, с. 67].

Отже, з однієї точки зору вирішення питання, що кнурячий запах це продукт змін, вироблений у значних кількостях генів $€$ дуже важливим і необхідним для здоров'я населення України та країн ЄС. 3 іншої точки зору, чи вбудовується в геном мітохондріальної ДНК «У» та «Х» хромосом людини пригнічення синтезу статевих гормонів та репродуктивної функції від спожитого продукту зі свинини при наслідку того, що метод імунологічної кастрації повністю не виводить стероїдні гормони з організму свиней, що потребує досліджень.

За сприйняття організмом свинок навколишнього середовища, відповідає рівень концентрації у крові - кортизолу, за що відповідає гормон стрес-фактор, він має значний вплив на якість м'яса у поєднанні 3 гормоном інсуліноподібного фактору росту IGF - відповідає за розвиток м'язових тканин та розподіл жиру. Асоційований зв'язок гормона (MC4R) меланокортиновий рецептор з (IGF) інсуліноподібний-фактор росту - відповідає за формування м'ясних та відгодівельних якостей свиней, а також взаємозв'язок кишкових рецепторів. На скільки часто зустрічаються алелі MC4C, MC4G. Застосування маркер залежної селекції (MAS) ДНК-маркерів асоційованих за рівнем продуктивності, мають вплив на фізіологічні та біологічні процеси в організмі [4, с. $165,145,146]$.

Проблема екології та благополуччя свиней різних статево-вікових груп буде вирішена на перспективу, як на внутрішньому ринку України, так і для експорту продукції свинини у країнах ЄС.

\section{Література:}

1. Барановський Д. І., Герасимов В. І., Сокрут О. В., Пронь О. В., Данілова Т. М., Хохлов А. М., Чалий О. І., Пасічник В. А., Слинько В. Г., Афанасенко В. Ю., Андрійчук В. Ф., Тарасенко Л. О. Свинарство: селекція, технологія. Еспада, 2011. 17с.

2. Квасницкий А. В. Искусственное осеменение свиней. К.: Урожай, 1983. 47. 
3. Лобашев М. Е. Генетика с основами селекции: Учеб. Пособие для студентов пед. ин-тов по биол. Спец. «Просвещение», 1979. 67 с.

4. Лобан Н. А. Геномная селекция в свиноводстве: РУП «Научнопрактический центр Национальной академии наук Беларуси по животноводству», 2013. 165, 145, 146 с.

DOI https://doi.org/10.30525/978-9934-26-047-6-9

\title{
ЖУКИ-СТАФІЛІНІДИ (СОLЕОРТЕRА: STAPНYLINIDAE: ALEOCHARINAE) РОДУ ZYRAS В КОЛЕКЦІЇ ІНСТИТУТУ ЗООЛОГІЇ ІМ. І. І. ШМАЛЬГАУЗЕНА НАН УКРАЇНИ
}

\author{
Глотов С. В.
}

молодший науковий співробітник відділу

музейного документування біоресурсів

Державний природознавчий музей Національної академії наук Украӥни м. Львів, Украӥна

\section{Гуштан Г. Г.}

кандидат біологічних наук,

молодший науковий співробітник відділу біосистематики та еволюиї Державний природознавчий музей Національної академії наук України м. Львів, Україна

\section{Гуштан К. В.}

кандидат біологічних наук,

молодиий науковий співробітник відділу музейного

документування біоресурсів

Державний природознавчий музей Національної академії наук України

м. Львів, Україна, викладач

Екологічний коледж

Львівського національного аграрного університету м. Львів, Україна

Рід Zyras Stephens, 1835 входить до складу підтриби Myrmedoniina, триби Lomechusini, підродини Aleocharinae. В світовій фауні відомо 